\title{
SECTIONS 351 AND 357(c) AFTER BONGIOVANNI, THATCHER AND FOCHT: PARITY FOR THE ACCRUAL BASIS TRANSFEROR
}

\author{
Phillp F. Postlewaite*
}

Pity the poor cash basis taxpayer. Woe is he who transfers cash basis receivables in a section 351 exchange if his accounts payable are assumed by the transferee corporation.

Following the Tax Court decision in Peter Raich, ${ }^{1}$ jurists and commentators alike have lamented the plight of cash basis transferors who face gain recognition in ostensibly recognition-free exchanges under section 351 of the Internal Revenue Code. ${ }^{2}$ These authors have argued for the elimination of the arbitrary and capricious application

* Associate Professor of Law, University of Notre Dame School of Law; B.B.A. 1967, Texas Christian University; J.D. 1969, University of California at Berkeley; L.L.M. in Taxation 1971, New York University.

The author wishes to thank Robert K. Kelley, a third-year law student at Notre Dame Law School when this Article was initially drafted and now a practicing attorney in Denver, Colorado, for his valuable assistance in preparing this Article.

THE FOLLOWING CITATIONS WILL BE USED IN THIS ARTICLE:

B. Bittker \& J. Eustice, Federal Income Taxation of Corporations and ShareHOLDERS (3d ed. 1971) [hereinafter cited as B. BITTKER \& J. EusTICE];

Del Cotto, Section 357(c): Some Observations on Tax Effects to the Cash Basis Transferor, 24 Buffalo L. REv. 1 (1974) [hereinafter cited as Del Cotto];

Dorman, Transfers of Liabilities to Controlled Corporations: A Problem Under Section 357(c), 1974 WIs. L. REv. 1017 [hereinafter cited as Dorman];

Kahn \& Oesterle, A Definition of "Liabilities" in Internal Revenue Code Sections 357 and 358(d), 73 Mich. L. Rev. 461 (1975) [hereinafter cited as Kahn \& Oesterle].

1. 46 T.C. 604 (1966).

2. Section 351 provides:

(a) General rule.-No gain or loss shall be recognized if property is transferred to a corporation by one or more persons solely in exchange for stock or securities in such corporation and immediately after the exchange such person or persons are in control (as defined in section 368(c)) of the corporation. For purposes of this section, stock or securities issued for services shall not be considered as issued in return for property.

(b) Receipt of property.- If subsection (a) would apply to an exchange but for the fact that there is received, in addition to the stock or securities permitted to be received under subsection (a), other property or money, then-

(1) gain (if any) to such recipient shall be recognized, but not in excess of-

(A) the amount of money received, plus

(B) the fair market value of such other property received; and 
of section 357(c) to cash basis transferors. They have asserted that such transferors are inherently disadvantaged by virtue of their selecting cash basis accounting methods before transfers to controlled corporations are even contemplated. ${ }^{3}$ This disadvantage, it is claimed, stems directly from the zero basis of trade receivables for cash basis taxpayers. $^{4}$

Concerned writers are quick to point out that section 357(c) operates mechanically, that is, without inquiry into tax avoidance motives. ${ }^{5}$ If liabilities ${ }^{6}$ are assumed by a transferee corporation in a transaction in which the only assets transferred are zero basis receivables, section 357 (c) literally assures taxable gain to the cash basis transferor, since the total liabilities assumed will exceed the aggregate basis of assets transferred. ${ }^{7}$ To be sure, accrual basis transferors are subject to section

(2) no loss to such recipient shall be recognized.

For a discussion of the operation and application of section 351, see text accompanying notes 21-22 infra. Commentaries in the area include: Del Cotto; Dorman; Kahn \& Oesterle; Roha, The Application of Section 357(c) of the Internal Revenue Code to a Section 351 Transfer of Accounts Receivable and Payables, 24 CATH. U.L. REv. 243 (1975); Comment, Section 357(c): The Quest for Equality Between Accrual and Cash Basis Taxpayers, 52 NEB. L. REv. 527 (1973); Comment, Section 357(c) and the Cash Basis Taxpayer, 115 U. PA. L. REv. 1154 (1967).

3. Taxpayers are afforded an opportunity under I.R.C. $\$ 446$ to select their method of accounting for tax purposes. The choice is generally between the cash and accrual methods, although other hybrid methods may be selected in particular circumstances. See I.R.C. \& 446(c). Under the cash basis method of tax accounting, income is taken into account when cash (or a cash equivalent) is received. Accrual basis taxpayers accrue income when the rights to such income become fixed or determined. Deductions under the two methods are similarly diverse, since payment is required for cash basis taxpayers, while a mere fixed obligation to pay is sufficient for an accrual basis taxpayer. See I.R.C. $\$ \S 451,461$ and the regulations thereunder. Regarding accounting methods generally see 1 S. SURREY, W. WARREN, P. MCDANIEL \& H. AULT, FederAl INCOME TAXATION 681-728 (1972).

4. Although the cash basis taxpayer has performed all necessary services and awaits payment, so long as the account is unpaid the taxpayer is not taxed and carries a zero basis. In contrast, the accrual basis taxpayer is taxed on each income item as soon as it is earned notwithstanding the taxpayer's lack of receipt. In such a case, the receivable is assigned a basis equal to that amount subjected to tax. See Treas. Reg. § 1.61-2(d)(2)(i) (1956). Thus, upon a subsequent disposition for an equal amount, double taxation is prevented through the basis mechanism.

5. Kahn \& Oesterle 461, 462.

6. The term "liabilities" appears in I.R.C. §357(c) without definition. As will be seen at text accompanying notes 67-81 infra, even the definitional aspect has generated numerous problems. If not limited definitionally as attempted by the court in Bongiovanni v. Commissioner, 470 F.2d 921 (2d Cir. 1972), the term certainly includes accounts payable. See text accompanying notes 57-66 infra.

7. Section 357(c) provides that the excess will result in gain recognition. The subsection states:

(c) Liabilities in excess of basis. -

(1) In general.-In the case of an exchange-

(A) to which section 351 applies, or

(B) to which section 361 applies by reason of a plan of reorganization within the meaning of section 368(a)(1)(D), if the sum of the amount of the liabilities assumed, plus the amount of the liabilities to which the property is subject, exceeds the total of the adjusted basis of the property trans- 
357(c) as well. However, the trade receivables transferred by accrual basis taxpayers generally have a basis equal to their face value. ${ }^{8}$ Therefore, it is less likely that total liabilities assumed will exceed the aggregate basis of assets transferred by the accrual basis taxpayer. ${ }^{9}$ Cash basis transferors arguably should not be forced to recognize gains in section 351 exchanges merely because of an accounting method employed prior to transfer. ${ }^{10}$ In other words, cash basis transferors should enjoy parity vis-à-vis accrual basis transferors.

Two courts of appeals and, more recently, the Tax Court have championed the cause of cash basis transferors. The Second Circuit in Bongiovanni v. Commissioner ${ }^{11}$ did so by using a definitional theory. The court excluded trade payables from the term "liabilities" within the context of section 357 (c); thus, the liabilities transferred by the cash basis taxpayer did not exceed the aggregate basis of his assets, including his zero basis receivables. Four years later, the Ninth Circuit in Thatcher v. Commissioner" adopted a "sale of receivables" approach-the same functional thinking which had been advanced in Judge Hall's dissent in the Tax Court's Thatcher decision. ${ }^{13}$ The court of appeals concluded in effect that tax accounting conventions do not change the true value of assets. Under that line of reasoning, cash basis receivables have true value similar to that of accrued receivables despite their zero basis. Viewing the payment by the transferee corporation of deductible trade payables as consideration for these valuable

\footnotetext{
ferred pursuant to such exchange, then such excess shall be considered as a gain from the sale or exchange of a capital asset or of property which is not a capital asset, as the case may be.

(2) Exceptions.-Paragraph (1) shall not apply to any exchange to which-

(A) subsection (b)(1) of this section applies, or

(B) section 371 or 374 applies.
}

See also Treas. Reg. § 1.357-2 (1955).

The gain recognized under section 357 (c) may be ordinary income or capital gain depending upon the nature and the character of the property transferred. B. BITTKER \& J. EUSTICE I 3.07, at 3-27.

8. See note 4 supra.

9. Obviously, the addition of other assets or liabilities will affect the mix of the aggregate transfer to which section 357(c) is applied. Section 357(c) is applied on an aggregate, rather than on an asset by asset, basis. See Treas. Reg. 1.357-2(a) (1955).

10. The court in Bongiovanni v. Commissioner, 470 F.2d 921 (2d Cir. 1972), expressed the concern most pointedly:

Congress certainly could not have intended such an inequitable result especially in light of its expressed purposes in enacting Sections 351 and $357(\mathrm{c})$. . . . We see no reason why different tax consequences under Section 357(c) should arise from identical circumstances because of the wholly unrelated selection of an accounting method. . Id. at 925 .
11. 470 F.2d 921 (2d Cir. 1972).
12. 533 F.2d 1114 (9th Cir. 1976).
13. Wilford E. Thatcher, 61 T.C. $28,42-44$ (1973) (Hall, J., dissenting). 
receivables, the Thatcher court held that the deduction would accrue to the cash basis transferor as an offset to any gain he recognized under section 357(c). More recently, the Tax Court in Focht $v$. Commissioner $^{14}$ reversed its prior holdings, which had applied section 357(c) literally, and adopted a definitional theory similar to that employed by the Bongiovanni court. The primary difference in the Focht analysis is that, under Focht, in order to be excluded from the section 357(c) definition of liabilities a payable must be a "deductible obligation" of the transferor. ${ }^{15}$

The underlying rationale of these decisions is to afford relief for cash basis transferors from "trap[s] for the unwary"16 - a desirable goal. However, it seems somewhat incongruous to argue that cash basis transferors suffer an inherent disadvantage because of their chosen system of accounting while ignoring the similar disadvantage which exists for accrual basis transferors. Accrual basis transferors are taxed directly on trade receivables accrued prior to a transfer to a controlled corporation. Yet, if cash basis receivables (upon which income has not been recognized) transferred in a section 351 exchange are taxable only to the transferee corporation upon their collection-frequently at a lower corporate rate than the rate to which the transferor would be subject-a disparity between cash and accrual basis taxpayers arises. ${ }^{17}$ Therefore, attempts to equalize treatment of cash and accrual basis transferors must not be limited to disparities created by section 357(c). Parity must be achieved across the entire spectrum of section 351 .

True parity between accrual and cash basis transferors under section 351 can only be achieved through the application of assignment of income (and its accompanying assignment of deduction) principles. The methods suggested by Bongiovanni, Thatcher, Focht and leading commentators in the field ${ }^{18}$ fail to achieve total parity. Application of the assignment of income doctrine to section 351 transactions by cash

\footnotetext{
14. 68 T.C. 223 (1977).

15. Id. at 237.

16. Bongiovanni, 470 F.2d at 924.

17. Individual tax rates in the highest marginal bracket are subject to a $70 \%$ rate of tax, I.R.C. \$.1; however, in most service activities, collection of such income as a sole proprietor might be subject to the preferential treatment of section 1348-maximum tax at a 50\% rate. In contrast to these high rates, a corporation's income is subject to either a $20-22 \%$ rate of tax, if its income is not in excess of $\$ 50,000$, or a $48 \%$ tax rate if its income exceeds $\$ 50,000$. See I.R.C. $\$ 11$. However, this immediate benefit may be coupled with the multiplier effect (creation of two potential gains rather than one) which offsets the above described benefit. See notes 79-81 infra and accompanying text. Furthermore, it is arguable that the accounts receivable are capital assets in the transferee's hands and therefore should be taxed at an even more preferential rate (30\%) under section
} 120(a).

18. See note 2 supra. 
basis transferors is desirable from a policy standpoint and is consistent with the postulate that substance, not form, shall govern the taxation of a transaction. ${ }^{19}$ Regardless of whether the courts adopt the use of assignment of income principles in section 351 transactions, ${ }^{20}$ they should reject the erroneous analyses recently advanced and should literally apply section 357 (c) to cash basis transferors.

\section{Section 357(C): AN Exception to NONRECOGNition UNDER SECTION 351}

Prior to analyzing the suggested assignment of income approach and its theoretical benefits, section 357(c) and the theories under which parity has been sought for the cash basis transferor must first be examined. Section 351 provides generally for tax-free transfers of pròerty to controlled corporations. More specifically, it dictates that neither gain nor loss shall be recognized if property is transferred to a corporation solely in exchange for the stock or securities of the transferee corporation, provided the transferors control the transferee immediately after the exchange. ${ }^{21}$ Section 351 is typically associated with the formation of new corporations, although it also applies to qualified transfers to existing corporations. ${ }^{22}$ Congress has traditionally viewed such transfers as purely a change in the form of business operations and thus not an appropriate taxable event. In other words, the change in technical ownership of assets that occurs in the typical section 351 transfer is merely a matter of form, there being no change in the substance and nature of pretransfer operations. ${ }^{23}$

There are two notable statutory exceptions to the basic recognition-free nature of section 351 exchanges. If money or other property, called "boot," is received by the transferor in addition to the stock and securities of the transferee corporation, gain realized on the transfer

19. See Commissioner v. Court Holding Co., 324 U.S. 331 (1945); Lucas v. Earl, 281 U.S. 111 (1930).

20. As discussed at text accompanying note 193 infra, it is arguable that, even if the assignment of income doctrine is not applicable to incorporation transfers, its application may still be consistent with section 357(c)'s underlying purpose.

21. I.R.C. $\$ \S 351(\mathrm{a}), 368(\mathrm{c})$. The text of section 351 appears at note 2 supra.

22. For a general discussion of incorporation problems and issues under section 351 see $B$. BITTKER \& J. EUSTICE 3-1 to 3-62.

23. Congress considered the provisions of section 351 as insuring "that the same tax consequences result from the different types of transactions which are available to accomplish substantially the same result." H.R. REP. No. 1337, 83rd Cong., 2d Sess. 40, reprinted in [1954] U.S. CODE CoNG. \& AD. News 4025, 4064. The same language also applies to section 357(c). Id. See text accompanying note 38 infra. See also Peter Raich, 46 T.C. 604 (1966), where the Tax Court was fearful that its decision "[might] conflict with the well established intent of Congress to foster tax free reorganizations." Id. at 611 . 
will be recognized up to the amount of the money and the fair market value of the property received. ${ }^{24}$ The rationale behind this provision is clear. Stock and securities represent an ownership interest in the transferee corporation; when they are used as consideration for the transfer, there has been a mere change in the form of ownership. To the extent that other valuable consideration passes to the transferor, there has been more than a change in form and taxation is appropriate.

Assumption of liabilities by the transferee corporation presents the second and more troublesome exception to the integrity of tax-free transfers to controlled corporations. ${ }^{25}$ Section 357(a) provides that the assumption of liabilities or of property subject to liabilities by a transferee corporation generally will not result in gain recognition. This provision is designed to maintain the recognition-free status of section 351 transactions by protecting the assumptions and transfers which follow in the ordinary course of converting from one business form to another. However, there are certain circumstances under which the assumption of liabilities by a transferee corporation will generate recognizable gain.

Section $357(b)^{26}$ provides that if the principal purpose of the transferor, in light of the circumstances surrounding the assumption of liabilities by the transferee corporation, is one of tax avoidance, or if the transfer lacks a bona fide business purpose, all liabilities assumed in the transaction will be treated as money received by the transferor, thereby creating "boot" and precipitating gain recognition. ${ }^{27}$ Section 357(b)

24. I.R.C. \& 351(b).

25. See I.R.C. $§ 357$.

26. I.R.C. \& 357(b) provides:

(b) Tax avoidance purpose.-

(1) In general.-If, taking into consideration the nature of the liability and the circumstances in the light of which the arrangement for the assumption or acquisition was made, it appears that the principal purpose of the taxpayer with respect to the assumption or acquisition described in subsection (1) -

(A) was a purpose to avoid Federal income tax on the exchange, or

(B) if not such purpose, was not a bona fide business purpose,

then such assumption or acquisition (in the total amount of the liability assumed or acquired pursuant to such exchange) shall, for purposes of section $351,361,371$, or 374 (as the case may be), be considered as money received by the taxpayer on the exchange.

(2) Burden of proof.-In any suit or proceeding where the burden is on the taxpayer to prove such assumption or acquisition is not to be treated as money received by the taxpayer, such burden shall not be considered as sustained unless the taxpayer sustains such burden by the clear preponderance of the evidence.

27. It is clear from the legislative history, however, that the gain will be recognized in the full amount of liabilities assumed regardless of whether the tax avoidance or non-bona fide business purpose exists with respect to only a portion of the liabilities assumed. See S. REP. No. 1622, 83d Cong., 2 d Sess. 270, reprinted in [1954] U.S. CODE CONG. \& AD. News 4621, 4908. See generally B. BitTKer \& J. Eustice 3-24 to 3-25; see also Treas. Reg. \& 1.357-1(c) (1961). 
serves to reduce the chances that the general rule of section 357(a) will be abused. For example, section 357(b) would generate gain recognition where a transferor borrows funds, securing the loan with property to be transferred in the section 351 exchange, and then transfers only the property subject to liability to the corporation while retaining the proceeds individually. Additionally, the assumption by the transferee corporation of the transferor's personal obligations, not normally associated with a business reorganization, would precipitate adverse tax consequences. ${ }^{28}$ In this way, section $357(\mathrm{~b})$ helps ensure that section 351 exchanges remain properly focused on changes in form only and prevents a disguised distribution of cash through an assumption of the liability by the corporation. ${ }^{29}$

In 1954, Congress went further to protect the purposes underlying tax-free transfers to controlled corporations by enacting section 357(c). That section provides simply that if the aggregate of liabilities assumed by the transferee corporation (including those to which transferred property is subject) exceeds the adjusted basis of all the property transferred, the excess will be treated as gain from the sale or exchange of the property transferred. The statute was intended to provide additional protection against tax avoidance. ${ }^{30}$ Its mechanical approach was in part adopted to sidestep the subjective inquiries necessary under

28. The burden of proving the existence of a bona fide business purpose falls on the taxpayer. Treas. Reg. \$ 1.357-1(c) (1961). See also Treas. Reg. \$1.351-3(a)(6), (b)(7) (1967).

29. A distribution of cash clearly constitutes boot and gives rise to adverse consequences. In the pre-transfer borrowing situation, the substance of the transaction is similar to a transfer of the property to the corporation in return for cash and stock. The distributed boot is funded through the corporation's borrowing against the transferred asset and/or its income potential.

30. It appears that the tax avoidance potential grew out of the uncertainty over whether a negative basis was possible under section 358. Many commentators argue that the legislative history is inconclusive. See Kahn \& Oesterle 471; Note, Donald D. Focht, 68 T.C. 223 (1977)_Section 357 Liabilities Do Not Include Deductible Liabilities of Cash Method Taxpayers, 31 TAX LAW. 243, 246 n.20 (1977). Others have suggested that the purpose of section 357(c) was to avoid a negative basis, since an assumed liability does not constitute boot under section 357(a) but does, for basis purposes, under section $358(\mathrm{~d})$. Thus, a negative basis would be a possibility in the absence of section 357(c). See Cooper, Negative Basis, 75 Harv. L. Rev. 1352, 1359 (1962); Comment, Section 357(c) and the Cash Basis Taxpayer, 115 U. PA. L. Rev. 1154 (1967). Others argue that the negative basis concern was a mere by-product of a purpose "to tax to the transferor of property the portion of the gain inherent in the property which represents tax free dollars already received by the transferor prior to transfer." Del Cotto 6 . If a negative basis were not possible, the gain potential would be permanently reduced by the amount of the liabilities in excess of the properties' bases to which the property is subject (e.g., a mortgage)-an unacceptable consequence. Assume that a taxpayer owned an asset with an adjusted basis of $\$ 20$, which was subject to a liability of $\$ 30$ and whose value was $\$ 100$. Upon transfer of the asset to a corporation for corporate stock worth $\$ 70$, the gain potential on the asset of $\$ 80$ would be reduced to $\$ 70$ if a negative basis were not permitted. Additionally, Congress may well have tired of the judicial reluctance to apply section $357(b)$ and assumed that such transfers fell within section 357(b). 
section 357(b) and to ensure that potential gain would be fully recognized.

It seems that the aims of sections 357(b) and 357(c) are identical. Both seek to curb abuse of tax-free transfers to controlled corporations by preventing taxpayers from incurring liabilities and then transferring them with immunity to a controlled corporation. However, because of its mechanical nature, section 357 (c) reaches beyond section $357(\mathrm{~b})$ and applies regardless of motive or purpose.

Application of section 357(c) has proved to be a "trap" for unwary cash basis transferors precisely because of this mechanical approach. ${ }^{31}$ For example, assume that a sole proprietor cash basis taxpayer decides to adopt a corporate form for his business. He has tangible assets in his business with a value of $\$ 25,000$ and a basis of $\$ 15,000$ and has trade accounts receivable of $\$ 50,000$, which, because he is a cash basis taxpayer, have a basis of zero. His only liabilities consist of $\$ 20,000$ in trade accounts payable, all of which represent invoices owed to various suppliers and all of which will qualify for a business deduction when satisfied. $^{32}$ Applying the literal language of section 357(c), the taxpayer must recognize $\$ 5,000$ of ordinary income on the transfer because this is the extent to which the liabilities $(\$ 20,000)$ exceed the aggregate adjusted basis of the assets transferred $(\$ 15,000) .^{33}$ Additionally, the stock received from the new corporation in exchange for the assets will have a basis of zero. ${ }^{34}$

If the taxpayer had employed an accrual basis accounting method prior to transfer, the transaction would have produced noticeably different results. ${ }^{35}$ He would have recognized no gain on the transaction and his stock would have had a basis of $\$ 45,000 .^{36}$ The courts have been critical of the statute because it apparently yields significantly different tax consequences for similarly situated taxpayers. ${ }^{37}$ However, it is a mistake to assume that the two transactions are identical and should consequently receive similar tax treatment. A critical differ-

31. See Bongiovanni, 470 F.2d at 924; B. BrrTKER \& J. EUSTICE at 3-27.

32. See I.R.C. § 162(a)(1).

33. The character of the gain is determined with reference to the type of assets transferred on a relative fair market value basis. See Treas. Reg. \$ 1.357-2(a) (1955) Ex. 1 \& 2. Thus, \$3333 would be ordinary income and the remaining gain (\$1667), depending upon the factual particulars under section 1231, would most likely be long term capital gain.

34. If section 357 (c) is applicable, the transferor's basis for corporate stock under section 358 will always be zero.

35. The accounts receivable would have a basis of $\$ 50,000$, subject to any allowance for bad debts under section 166.

36. I.R.C. \& 357(c) would not have been applicable and section 358 would have yielded a basis of $\$ 45,000$.

37. See note 10 supra. 
ceeded the aggregate basis of assets transferred of $\$ 11,300 .^{43}$

Raich argued that his trade receivables should be afforded a basis equal to the amount of trade payables assumed by the corporation, that is, $\$ 37,700$. He contended, citing section 1012 , that such a basis was accurate because it would reflect his cost in generating receivables. ${ }^{44}$ Alternatively, Raich argued that under the authority of N.F. Testor, ${ }^{45}$ section 357(c) was inapplicable because he received no economic benefit from the transfer. ${ }^{46}$ In Testor, the transferor received an economic benefit because the aggregate liabilities assumed exceeded not only the aggregate basis of property transferred but also the value of that property. Since the value of his receivables exceeded his liabilities, Raich argued that under Testor no economic benefit was derived and thus no tax should result. ${ }^{47}$

The court found that section 357(c) applied regardless of Raich's argument that he received no economic benefit from the transfer. The court could not find any indication from the legislative history or the statute itself that application of section 357(c) is limited to cases where transferors derive economic benefits. ${ }^{48}$ It also rejected Raich's "costbasis" theory because the record did not reflect a finding that the transferor's receivables were encumbered by creditor's liens. ${ }^{49}$ Therefore, the basis of the receivables was zero and Raich was forced to recognize $\$ 34,700$ of ordinary income. ${ }^{50}$

The Tax Court has repeatedly imposed similar tax consequences upon cash basis taxpayers by literal applications of section $357(\mathrm{c}) .^{51}$ Short of judicial vindication or legislative change, cash basis transferors were forced to decide whether to accept their fate under section 357(c) as interpreted by the Tax Court or to attempt to utilize their foresight and suggested tax planning techniques.

Several such techniques were available. In anticipation of a transfer to a newly formed corporation, the cash basis taxpayer could request a change of accounting method under section 446(e). ${ }^{52}$ However, this change, presumably to an accrual basis, would put an

43. $I d$.

44. Id. at 609-10.

45. 327 F.2d 788 (7th Cir. 1964).

46. 46 T.C. at $608-09$.

47. $I d$.

48. $I d$.

49. Id. at 610 .

50. Id. at 611 .

51. See text accompanying notes 39-40 supra.

52. Such a last minute approach was attempted in Bongiovanni but was disallowed by the Tax Court. 470 F.2d at 922. 
ence is that the accrual basis taxpayer has previously recognized the income attributable to the receivables. Such is not the case for the cash basis taxpayer. Without the invocation of the assignment of income doctrine, the transfer of receivables, previously unreported as income and thus having a zero basis in the hands of the transferor, is equivalent to a transfer of an appreciated asset to a corporation. Thus, the situation is not identical to that of the accrual basis taxpayer whose receivables have acquired a tax basis equal to their face value through the recognition of income in that amount.

Ideally, cash and accrual basis taxpayers should receive identical treatment of receivables for purposes of sections 351 and 357(c). Such an approach would be consistent with the goals behind the enactment of those sections. ${ }^{38}$ However, as discussed below, this similarity of treatment is not achieved by straining the meaning and intent of section 357(c). If, instead, the assignment of income doctrine is applied, parity between the two similarly situated taxpayers ensues and any problems created by applying section 357 (c) to cash basis taxpayers are eliminated. However, without such an approach, a literal application of section $357(\mathrm{c})$ is necessary since the taxpayers' situations are not identical.

\section{Literal Application: The Raich ApProach}

The Tax Court, prior to its recently issued Focht decision, had consistently enforced section 357(c) literally. Tax Court decisions beginning with Peter Raich ${ }^{39}$ doggedly clung to precise application of its provisions. ${ }^{40}$ In Raich, a cash basis sole proprietor transferred all the assets and liabilities of his business to a new corporation under section 351. The transferee corporation thereby acquired assets with an approximate aggregate basis of $\$ 11,300$ along with trade receivables of about $\$ 77,300{ }^{41}$ The new corporation also assumed liabilities of approximately $\$ 46,000$, of which $\$ 37,700$ were trade payables. The Commissioner argued that section 357(c) applied to the transaction because liabilities assumed exceeded the aggregate basis of assets transferred by $\$ 34,700 .{ }^{42}$ The Commissioner reached this result by attributing a zero basis to the receivables; thus, the liabilities assumed of $\$ 46,000$ ex-

38. See note 23 supra.

39. 46 T.C. 604 (1966).

40. See Note, supra note 30 , at 243 n.4. The court has, however, expressed reservations about the propriety of its position. Raich, 46 T.C. at 611 . See note 23 supra.

41. 46 T.C. at 605 .

42. Id. at 607 . 
accrual basis taxpayer at a relative disadvantage if the cash basis taxpayer were to receive a stepped up (accrual) basis for the receivables generated prior to the change in methods without a concomitant recognition of income, thereby frustrating a search for parity under section 351. Consequently, Revenue Procedure $70-27^{53}$ conditions approval of requests for accounting methods changes upon taxpayer consent to income adjustments over a ten-year period beginning with the year of the change. Even with such a protection, a cash basis transferor might well be able to prorate the tax consequences flowing from pre-election receivables over a ten-year period, while a similarly situated accrual basis taxpayer's receivables already would have been taxed to him in full. More fundamentally, there is no sound policy reason why taxpayers should change from an accounting method that presumably reflects income clearly in order to avoid disguised tax disadvantages. In fact, it could be argued that the new method would not clearly reflect income at all, but would overcompensate for the consequences traditionally befalling the cash basis taxpayer. ${ }^{54}$

Alternatively, the cash basis transferor could transfer other suitable property not subject to liability so as to increase the aggregate basis of assets transferred. In the example discussed above, ${ }^{55}$ the transferor could have transferred additional money $(\$ 5,000)$ or property with a basis of $\$ 5,000$ to prevent his aggregate basis from exceeding liabilities, thereby avoiding the applicability of section 357(c).

Other tax planning approaches would be for the transferor (1) to withhold all receivables and payables from the transaction, collecting receivables, and satisfying the payables with the proceeds; (2) to withhold only a portion $(\$ 5,000)$ of the liabilities and payables, so that again the aggregate basis of assets transferred equals or exceeds the liabilities; or (3) to sell his receivables to the transferee corporation, retaining the payables and satisfying them with the sale proceeds. ${ }^{56}$ The transferor would be able to offset receipts for tax purposes by the deductions flowing from the satisfaction of trade payables.

53. 1970-2 C.B. 509; modified by Rev. Proc. 74-51, 1974-2 C.B. 508 and clarified by Rev. Proc. 75-18, 1975-1 C.B. 687 . See also Shore v. Commissioner, 69 T.C. 689 (1978).

54. This point was missed by the Bongiovanni court. In its decision, the court noted that a change of accounting method would avoid the 357(c) adverse tax consequences and felt that the "inadvertent" choice of accounting method should not disadvantage the taxpayer. $470 \mathrm{~F} .2 \mathrm{~d}$ at 924. However, the court lost sight of the additional tax consequences incurred in such a change of method-inclusion of such income by the taxpayer (a consequence not incurred under a cash basis method of accounting).

55. See text accompanying notes 31-36 supra.

56. Under any of these effective tax planning techniques section 357 (c) would not be applicable. 
Clearly, then, section 357(c) can be avoided by cash basis taxpayers through appropriate foresight. However, many cash basis transferors fail to consider the consequences of section 357(c) and do not take advantage of tax planning opportunities prior to the transfer. Two courts of appeals and the Tax Court have recently handed down decisions affording relief to taxpayers who find themselves in this predicament. The decisions espouse two different approaches, one definitional, the other more functional. Both approaches fail in two respects. First, both fail to recognize that, even after their application, full parity has not been achieved between accrual and cash basis transferors in section 351 transactions. Second, both fail to affirm that section 357(c) has validity in terms of its intended purpose to provide a safeguard against abuse in transfers to controlled corporations.

\section{Relief For the CASH Basis TRANSFEROR: INTERPRETATIONS OF SECTION 357(c)}

\section{A. Definitional Approach.}

Bongiovanni v. Commissioner ${ }^{57}$ represents the first major decision offering relief to cash basis transferors after the Tax Court's holding in Raich. Bongiovanni was a cash basis sole proprietor. He transferred all of the proprietorship's assets, including trade receivables, to a new corporation in a section 351 exchange. In return, the new corporation exchanged all of its stock, issued a promissory note and assumed the transferor's trade payables. As the trade receivables had a basis of zero, the aggregate basis of assets transferred was approximately $\$ 1,400 .^{58}$ The Tax Court found that the assumed trade payables of $\$ 17,200$ generated $\$ 15,800$ of gain under section $357(\mathrm{c}){ }^{59}$ The Second Circuit focused upon the relationship between trade payables and the meaning of liabilities within section 357(c). The court reversed the Tax Court, holding that trade payables are not liabilities within the meaning of the section and thus that section 357(c) did not apply to the transaction. ${ }^{60}$ The court's holding was predicated primarily upon the illustration used both in the legislative history and the regulations to highlight the operation of section 357(c). ${ }^{61}$ This example refers specifi-

57. 470 F.2d 921 (2d Cir. 1972).

58. Id. at 922 .

59. Id. at 922-23.

60. Id. at 923-24. The court concluded that "liabilities" are not to be equated with liabilities in a strict accounting sense, but are restricted to what the court termed " 'tax' liabilities, i.e., liens in excess of tax costs, particularly mortgages encumbering property transferred in a section 351 transaction." Id. at 924.

61. See [1954] U.S. Code Cong. \& AD. News 4064, 4266-67, 4908; Treas. Reg. \& 1.357-2(a) (1960), T.D. 6528, 1961-1 C.B. 79. 
cally to land encumbered by a mortgage which exceeds the basis of the land itself. The court concluded that to lump trade payables together with mortgages as section 357(c) liabilities would lead to absurd results in the case of a cash basis taxpayer whose trade payables may not be deducted until paid. ${ }^{62}$ "The payables of a cash basis taxpayer are "liabilities' for accounting purposes but should not be considered 'liabilities' for tax purposes under section 357(c) until they are paid." ${ }^{\prime 3}$

While the court purported to distinguish the treatment of cash basis trade payables in the light of legislative intent or history, the holding more accurately represents judicial legislation designed to avoid inequity resulting from "a too literal reading of the words of the statute." Clearly, the court felt that the inequity suffered by Bongiovanni as a result of section 357 (c) stemmed directly from his chosen method of accounting. Accordingly, the court altered the customary meaning of "liabilities" to prevent a cash basis taxpayer from falling into a trap for the unwary. It premised its holding upon the fact that accounting methods should not dictate different results under section 357(c): "We see no reason why different tax consequences under section 357(c) should arise from identical circumstances because of the wholly unrelated selection of an accounting method." 65 In other words, the court held that cash and accrual basis taxpayers should receive equal treatment, at least on the facts presented in the instant case. Though seeking a worthwhile goal, the court in fact failed to achieve parity between cash and accrual basis taxpayers and overlooked the fact that cash and accrual basis taxpayers are not similarly situated. ${ }^{66}$

\section{B. Criticism of the Bongiovanni Approach.}

The Second Circuit's analysis of section 357(c)'s application to cash basis transferors is unsatisfactory for a number of reasons-it finds no support in the legislative history and leads to confusion and

62. 470 F.2d at 924 .

63. Id. at 924 (emphasis in original). The Bongiovanni court, in anticipating a response to its position, stated: "It is no answer to say that the taxpayer's wholly-owned corporation will eventually reap a benefit which will redound to the appellant. The corporate taxpayer would be entitled to its deduction whether or not the cash basis individual taxpayer had been taxed under Section 357(c)." Id. at 925. However, Treas. Reg. § 1.461-1(a)(2) (1957), which was cited by the court as authority, does not stand for such a proposition. Furthermore, under the Bongiovanni approach the goal of parity is undercut: since an accrual basis transferor has received a deduction for trade payables, his transferee corporation would not be entitled to one. Thus, the cash basis taxpayer receives a double benefit-the nonapplication of section 357(c) coupled with a deduction available to the corporation.

64. Bongiovanni, 470 F.2d at 924.

65. Id. at 925 .

66. See text following note 37 supra. 
inconsistency when the definition is extended beyond the narrow confines of section 357(c). Even when it is restricted to section 357(c), a detailed analysis reveals the fundamental error of the Bongiovanni approach.

There is no compelling historical basis to justify a new, more limited definition of liabilities for purposes of section 357(c). Nothing in the statute or its legislative history indicates that the term "liabilities" does not include the trade payables of a cash basis taxpayer ${ }^{67}$ and there is no reason to assume that Congress did not contemplate application of the section to cash basis transferors who typically have substantial trade payables whose value might exceed the basis of the taxpayer's assets. ${ }^{68}$ Indeed, if trade payables of a cash basis taxpayer are to be excluded, the court's insistence upon parity between cash and accrual basis taxpayers leads to the conclusion that the same treatment should necessarily be afforded to accrual basis taxpayers as well, thereby seriously emasculating the protective purposes of section 357(c) ${ }^{69}$ The mere fact that the legislative history and the regulations utilize mortgage situations to illustrate section 357 (c)'s operation is no reason to conclude that the term does not include nonlien liabilities such as accounts payable. Moreover, the Ninth Circuit and the Tax Court have specifically refused to follow Bongiovanni, holding instead that the term "liabilities" must be interpreted by its normal meaning-which includes trade payables. ${ }^{70}$

More fundamental problems are posed by the Bongiovanni court's tampering with the language of the statute. When the redefinition of the term "liabilities" is put to work in other subsections of section 357, and in other sections of the Code, the results are at best unpredictable and at worst disastrous. For example, if a trade payable is not a liability under section 357 (c), then it should not be treated as a liability under section 357(a). Thus, it is outside that subsection's general protective

67. See text accompanying note 120 infra.

68. If Congress failed entirely to foresee the consequences to cash basis taxpayers, as many commentators and jurists have stated, see note $\mathbf{3 0}$ supra, there are no grounds for arguing that those consequences are against the underlying policy of section 351 .

69. Furthermore, under such an approach it could be argued by analogy that other Code sections using the term "liabilities" should be similarly defined. See sections 311(c) and 752 as examples of other Code provisions employing the term. Judge Hall, dissenting in Focht v. Commissioner, 68 T.C. 223 (1977), stated that the term "liability" appears in the Code 400 times. Id. at 244 (Hall, J., dissenting). See text accompanying notes 71-73 infra.

70. Thatcher v. Commissioner, 533 F.2d 1114, 1117 (9th Cir. 1976); Focht v. Commissioner, 68 T.C. 223, 229 (1977). As noted by Judge Hall in her dissenting opinion in Focht, such a definition is "inconsistent with the plain wording of the statute." Id. at 243 (Hall, J., dissenting). For further criticism of the Bongiovanni approach, see Kahn \& Oesterle 479-80. 
provision and must be treated as boot, triggering gain recognition. ${ }^{11}$ Although such a result is clearly inconsistent with the court's goal of offering relief to the cash basis taxpayer, there is nothing in the court's rationale to preclude this extension-an inherent danger in the definitional approach to judicial legislation.

A particular definitional dilemma is posed with respect to the policy underlying section $357(\mathrm{~b})$. As sections $357(\mathrm{~b})$ and (c) utilize the identical term "liabilities," that term should be similarly defined in both subsections. However, if "liabilities" under section 357(b) are interpreted according to the Bongiovanni construction, the policy of that section will be undercut. A trade payable may by definition not be the type of liability that would be incurred for tax avoidance or nonbusiness purposes; yet, if another tax liability is transferred for a tax avoidance or non-business purpose, all liabilities are treated as boot. ${ }^{72}$ It is difficult to imagine that Congress did not intend the "boot" treatment of section 357(b) to extend to trade payables in such a situation. However, since any redefinition must reach both sections to provide definitional consistency, such an approach undercuts section 357(b). ${ }^{73}$

Even when strictly confined to section 357 (c) ${ }^{74}$ the Bongiovanni approach fails to fulfill its ultimate goal-parity between cash basis and accrual basis taxpayers. The court overlooked the fact that true parity cannot be achieved without equalizing the pretransfer tax effects of the two different accounting methods. The accrual method taxpayer has recognized income and claimed deductions; the cash method taxpayer has not. If a simple assignment of receivables outside of section 351 were involved, such as, in a gift situation, the need for equalization would be apparent, and assignment of income principles would clearly apply to the cash basis transferor. Equalization of tax effects can be

71. See text accompanying note 24 supra.

72. See text accompanying note 27 supra.

73. At another level, the Bongiovanni decision may be criticized on the grounds that the court was subject to statutory confusion-applying section 357(b) rather than section 357(c) to the facts presented. The court, in justifying its conclusion, mentioned that no tax avoidance motives were present. It seemingly confused the subjective standard for generation of gain under section 357(b) with the standard of section 357 (c), which operates automatically without regard to motive.

74. The Bongiovanni court failed to express an opinion on the consequences of a transfer pursuant to section 351 in which the amount of payables transferred exceeds the value of the receivables. If the court were to consistently follow its definitional approach, the trade payables would not precipitate gain under section $357(\mathrm{c})$, even though such a situation would surely constitute a compelling case for gain recognition. Clearly the Testor rationale of economic benefit would apply in such a case. A subsidiary issue would be the amount of gain recognition in such a situation. There are at least three possibilities: (1) the excess of payables over receivables, (2) any excess of payables over receivables and other assets or (3) the total excess of all liabilities (including payables) over aggregate basis. 
equally well achieved by applying those principles under sections 351 and 357(c).

The problem presented by the Bongiovanni approach is best illustrated by use of the figures from the example discussed above. ${ }^{75}$ For the accrual method taxpayer, net income of $\$ 30,000$ is realized prior to the transfer and must be recognized. The taxpayer's adjusted basis for stock with a value of $\$ 55,000$ received in a section 351 exchange is $\$ 45,000$; thus, upon sale of his stock the taxpayer will recognize a further gain of $\$ 10,000$ based on the appreciation of tangible assets. The cash basis taxpayer, on the other hand, recognizes no income before the transfer and, under Bongiovanni, has no 357(c) gain upon the transfer. Assuming liabilities are similarly defined for section 358(d) purposes, ${ }^{76}$ he would have a basis of $\$ 15,000$ for stock worth $\$ 55,000$. If there is no subsequent appreciation in value, the sale of stock would generate gain of $\$ 40,000$, probably taxable as capital gain. ${ }^{77}$ Although total gain of $\$ 40,000$ is ultimately recognized in both cases, true parity has still not been achieved. The cash basis shareholder's potential ordinary income is converted to preferentially treated capital gain, and all of the shareholder's gain is deferred past the date of actual collection of the receivables. ${ }^{78}$

If the cash basis taxpayer's transfer of receivables is not treated as an assignment of income, it clearly must be seen as a transfer of appreciated assets because of their zero basis. A transfer of appreciated property under section 351 triggers a "multiplier effect." The recognizable gain is doubled since, after the transfer, the carryover of basis provisions require that it exist at both the individual and the corporate

75. See text accompanying notes 31-36 supra.

76. From Bongiovanni it is uncertain whether the term "liabilities" should be similarly interpreted for the basis provisions of section 358(d). Some commentators supporting the decision have so interpreted the term, stressing that parity is thereby achieved. However, such a position ignores the reality of the situation described in the text and allows the taxpayer an economic benefit in that he is relieved of his trade payable obligation with no decrease in his basis in the stock. The transferee's basis under section 358(d) when section 357(c) applies is always zero, which supports the view that section 357 (c) was enacted to prevent a negative basis. See B. BITTKER \& J. EUSTICE 3-27. See note 30 supra. However, some commentators, fearful that the elimination of a portion of the gain from taxation will occur, assert that the logical and proper consequence of Bongiovanni is a negative basis. B. BITTKER \& J. Eustice 53-7 (Cum. Supp. 1978). See also Kahn \& Oesterle 480 . This is precisely what Congress sought to avoid.

77. Corporate stock generally constitutes a capital asset under section 1221 and, depending upon the holding period, will generate long term capital gain upon its sale under section 1222(3). An overriding exception is the collapsible corporation doctrine of section 341 which, under certain circumstances, generates ordinary income upon the disposition. See I.R.C. $\$ 341(b)(3)$ (C) for the application of this doctrine to the transfer of "unrealized receivables."

78. As the transferred receivables are equivalent to an appreciated asset, this emphasis on dollar equivalence fails to consider the multiplier effect. See notes 79-81 infra and accompanying text. 
level. ${ }^{79}$ The accrual basis taxpayer who transfers receivables with a substantial basis is not subject to the multiplier effect because his property is not appreciated, whereas the cash basis taxpayer must face these potentially adverse consequences. Section 357(c) ameliorates the multiplier effect to some extent because recognized gain is added to the basis both of the stock and the property transferred. ${ }^{80}$ The application of the assignment of income doctrine would entirely eliminate the multiplier effect. ${ }^{81}$ Failing that, a strict application of section 357(c) is the only logical means of lessening its effect without overlooking the real differences in the situation of cash and accrual basis transferors.

As the above discussion illustrates, the Bongiovanni decision is based upon a misinterpretation of section $357(\mathrm{c})$, and its proponents misunderstand the consequences of that interpretation. The decision therefore should not be followed.

\section{Functional Approach.}

A functional approach to the problems raised by section 357(c) was offered by the Ninth Circuit in Thatcher v. Commissioner. ${ }^{82}$ Reversing the decision of the Tax Court, Thatcher rejected Bongiovanni's definitional solution and supplanted it with a "sale of receivables" theory.

Thatcher involved a classic section 357(c) fact pattern. A partnership transferred all of its assets in a general contracting business to a new corporation. In exchange, the new corporation transferred all of its stock to the transferor and assumed the partnership's liabilities.

79. Thus, in the simplest example, a taxpayer with an appreciated asset worth $\$ 100$ with a basis of $\$ 20$ would recognize an $\$ 80$ gain on its disposition. However, if transferred for stock worth $\$ 100$, the basis for the stock under section 358 is $\$ 20$ (a gain potential of $\$ 80$ exists with respect to the stock). Yet, under section 362 the corporation's basis for the transferred asset is also $\$ 20$, thereby yielding another potential gain should the corporation dispose of the asset. Thus, two gain potentials arise after incorporation where only one existed before corporate formation. This "multiplier" effect is inherent in the use of the corporate entity and the transfer of accounts receivable by a cash basis taxpayer yields such results.

80. Del Cotto loses sight of this critical difference both in noting that a significant difference in result occurs and in expecting parity. Since the transferor employs a cash method of accounting, the transfer of the assets causes the multiplier effect to occur. Del Cotto 14. The recognition of income under section 357(c) constitutes gain which, through the corporate basis provisions of section 362 , affords the corporation an increased basis, thereby reducing the gain potential remaining at the corporate level.

81. See text accompanying notes $148,150-51$ infra. In the example at note 79 supra, the doctrine would result in a recognition of all the income and, thus, the transferor would be deemed to transfer the $\$ 100$ of cash, giving him a basis under section 358 of $\$ 100$, and the corporation would have $\$ 100$ in assets. If it were to purchase an asset for that amount, the basis would be \$100. I.R.C. $\$ 1012$.

82. 533 F.2d 1114 (9th Cir. 1976). 
The partnership used a cash basis method of accounting. ${ }^{83}$ Included among the transferred assets were $\$ 317,000$ of trade receivables. Of the liabilities assumed by the new corporation, $\$ 164,000$ were accounts payable incurred in the business. ${ }^{84}$ Finding that the receivables transferred had a zero basis, the Tax Court held that the partnership recognized taxable gain on the transaction of $\$ 102,300$, that is, the excess of aggregate liabilities assumed over the aggregate basis of assets transferred. ${ }^{85}$ The court rejected the partnership's argument that receivables should be assigned a basis equal to the amount of payables incurred to produce them and disallowed the partnership's reliance on the Second Circuit's holding in Bongiovanni. The court concluded that any solution to the taxpayer's problem was a legislative one and must therefore await congressional reconsideration. ${ }^{86}$

Five Tax Court judges were unwilling to rely on corrective legislative action and offered two alternative theories of relief for the cash basis transferor. Judge Quealy, joined by Judge Goffe, expanded upon Bongiovanni's definitional gambit, ${ }^{87}$ defining "liabilities" to include only those obligations that actually have been taken into account in determining the cash basis taxpayer's income and expense. ${ }^{88}$ For the reasons discussed above, ${ }^{89}$ such a definitional approach is unacceptable.. ${ }^{90}$

Judge Hall's dissent, joined by Judges Forrester and Featherston, adopted a more pragmatic theory to offset the adverse consequences of section $357(\mathrm{c}) .^{91}$ While upholding the standard meaning of liability, Judge Hall theorized that in the typical transfer of receivables and payables by a cash basis taxpayer, the taxpayer constructively sells a portion of his receivables equal to the excess of liabilities transferred over aggregate basis to the transferee corporation. In consideration, the transferee corporation agrees to satisfy the transferor's trade payables. When the corporation satisfies those payables, the transferor is allowed to offset his receipts from the constructive sale. Therefore, the entire transaction is a wash and gain under section 357(c) ultimately is offset by deductions to the extent generated by trade accounts payable. ${ }^{22}$

83. Id. at 1116 .

84. Id. at $1116 \mathrm{n} .4$.

85. Wilford E. Thatcher, 61 T.C. 28 (1973).

86. Id. at 37 .

87. Id. at 39-40 (Quealy, J., concurring and dissenting).

88. For a further discussion of this approach see Kahn \& Oesterle 480-81.

89. See text accompanying notes 67-81 supra.

90. Interestingly, although the court of appeals commended the result in Bongiovanni, it rejected the definitional approach in its holding. $533 \mathrm{~F} .2 \mathrm{~d}$ at 1117.

91. For an analysis of Judge Hall's approach see Dorman 1055-60.

92. Thatcher, 533 F.2d at 1117 (discussing 61 T.C. at $42-44$ (Hall, J., dissenting)). 
The Ninth Circuit adopted the Hall rationale as its own..$^{93}$ The court was careful to point out that such an approach preserves the intended operation of sections 351 and 357 while preventing an upwarranted and inequitable application of section 357(c)..$^{94}$

\section{Critical Analysis of Thatcher.}

The Thatcher approach bifurcates the operation of section 351. It postulates, in effect, that what was once a single transaction is now two. Part one is a sale of receivables to the transferee corporation; part two is a section 351 exchange of the remaining assets following the sale. If a transaction meets the statutory criteria, it is considered a section 351 transaction and qualifies for nonrecognition treatment. Section 357(c), while affecting the tax results of certain section 351 exchanges, does not modify the general nature of such transactions by attributing sale'treatment to one component and exchange treatment to another.

Regardless of whether gain is recognized in such a transaction, its nature is not even in part that of a normal exchange or sale. Thus, the Thatcher decision in essence effectuates judicial tax planning. ${ }^{95}$ While these efforts should be applauded for avoiding, to a limited extent, an assignment of the transferor's income to the corporation, ${ }^{96}$ the approach is not grounded on sound tax theory; it fails to reach all of the receivables, isolating those which generate section 357(c) gain for special treatment. ${ }^{97}$ Furthermore, since only a portion of the income is imputed to the transferor, thereby leaving substantial differences in overall tax results between cash and accrual basis taxpayers, this approach does not achieve total parity as would the assignment of income doctrine.

A further theoretical inconsistency lies in the assumption that the offsetting deduction is available only when the payables are paid by the

93. Id. at 1118 .

94. Id. at 1117-18. The court also made the following observation of its adopted approach: "While the wash, or setoff, solution is not without its own doctrinal difficulty, it is consistent with the spirit of section 351 , as it prevents wholly unwarranted tax windfalls in favor of the government." Id. at 1117. Even more interesting is the court's assertion that "[t]his approach encroaches upon the strict construction of cash-basis accounting." Id. at n.8. The court ignored the tax windfall to the transferor through his ability to shift the income from receivables to the other entity.

95. The ultimate result is the same as alternative (2) in the text accompanying note 56 supra.

96. See notes 134-51 infra and accompanying text for a discussion of an approach which would prevent the transferor from successfully assigning any of his receivables income to the transferee corporation.

97. Under this approach, only the section 357(c) gain-generating receivables are isolated, while the assignment of income doctrine isolates all the transferor's receivables. See notes $143-44$ infra and accompanying text and text accompanying notes 91-92 supra. 
transferee corporation. ${ }^{98}$ If the sale analogy is, in fact, appropriate, then the netting effect would occur immediately. ${ }^{99}$ Thus, the corporation is viewed as an agent for one-half of the "sale" transaction (payment of payables), but is simultaneously viewed as an outside purchaser of the receivables. The assignment of income doctrine would consistently apply the agency rationale with respect to both the payables and receivables. ${ }^{100}$

An additional problem in the netting approach is how the sale, which generates offsetting income and deductions, further offsets the section 357(c) gain. Apparently, a significant theoretical step is required to reach such a conclusion. In reality, the approach taken by the Ninth Circuit is a partial assignment of income approach. Under sound tax theory a court can arrive at the Ninth Circuit's conclusion only by maintaining that the taxpayer withheld receivables equal to the amount of his payables. Thus, no section 357(c) gain arose and the income from the withheld receivables as collected is offset by the deduction for the payables when paid. This construction generates the same results as Thatcher, but without that decision's artificiality and inconsistency with cash basis tax accounting procedures.

Additional theoretical problems in Thatcher are those discussed in Bongiovanni. If payables exceed receivables, what would be the consequences to the taxpayer? ${ }^{101}$ Under the Thatcher approach, would the Ninth Circuit conclude that other appreciated property was "constructively sold" for the payables with the attendant problems of characterizing the gain? ${ }^{102}$ Or would the Ninth Circuit instead allow recognition of the excess as section 357(c) gain with no offsetting de-

98. In Thatcher, since the corporation paid all payables during the year, the issue was not presented. However, language in the opinion clearly indicates that payment of the payables is controlling and gives rise to the offsetting deduction. The court noted that "[ $[$ ] he consideration to be received is extinguishment of the transferor's payables. When the transferor-corporation provides that consideration, the cash basis transferor should be able to recognize the now-completed sale of receivables." 533 F.2d at 1117-18 (emphasis added). The court offered the rationale that since there was no statutory recognition of the asserted deduction, no deduction would be allowed until actual payment is made. Id. at 1118 .

99. See Commissioner v. P.G. Lake, Inc., 356 U.S. 260 (1958), in which the taxpayer assigned a right to future oil payments in return for cancellation of its indebtedness. Finding that the assignment constituted a sale, the Court held that income was recognized immediately as ordinary income rather than as capital gain. A right to payment existed and its sale constituted an acceleration of ordinary income.

100. See notes 134-51 infra and accompanying text.

101. See note 74 supra. See Del Cotto 15-20.

102. See Note, supra note 30 , at 255 . See also Focht v. Commissioner, 68 T.C. 223,237 n.28 (1977). Gain under section 357(c) is characterized by the nature of the assets transferred, and thus capital gain may be recognized with the subsequent offset (payment of payables) generating ordinary loss deductions. Additional benefits are thereby derived. See also Dorman 1058. 
duction for the satisfaction of the excess payables, in which case further distortion arises? Finally, what would be the result to the transferor's basis for his stock in such a case? In contrast to Bongiovanni, under the Thatcher approach a failure to redefine the term "liabilities" yields a zero basis at all times. ${ }^{103}$

Another problem with the Thatcher approach is the distortion that arises with respect to the tax treatment of the transferee corporation. One would assume that the corporation would not be entitled to a deduction for its payment of the payables; otherwise, a double benefit would ensue - two parties deducting the payment of the same item. While the point is not particularly clear in Thatcher, Judge Hall in her dissent in Focht concluded that the payables are nondeductible to the transferee and are instead considered a cost of acquiring the transferred assets. ${ }^{104}$ Yet this approach seemingly yields the double benefit of deduction by one party and a basis adjustment by the other on the same event. ${ }^{105}$ Further, in the context of determining the corporation's basis under section 362, unless the section 357(c) gain is considered "offset," the corporation would receive an additional step-up in basis. ${ }^{106}$ Even if gain is to be offset by actual payment of the payables, if the payables are paid in a subsequent taxable year the corporation would receive a temporary increase in basis for the assets, which, if depreciable, produces further distortion-precisely the type of problem which the United States Supreme Court attempted to avoid with its decision in Crane v. Commissioner. ${ }^{107}$

103. This result should be contrasted with the basis determination under the Bongiovanni approach. See text accompanying notes 75-78 supra.

104. 68 T.C. at 248 (Hall, J., dissenting). See also Note, supra note 30, at 256 n.87. But if such amount is transferred to the assets when paid, additional tax benefits are available.

105. The satisfaction of payables by the corporation affords to the transferor an offetting deduction, while the corporation increases the basis of its assets by such amount. Such an increase reduces the amount of gain which could be recognized on a subsequent disposition. Contrast the "acquisition cost for assets" under section 362 described by B. BITTKER \& J. EUSTICE 343 If 3.12, through which no adjustment ot the corporation's "inherited tax basis" is made. If such is the Thatcher approach, then the double benefit would not ensue.

106. Under section 362, the corporation's basis is increased by the gain recognized to the transferor on the transfer. Thus, the section 357(c) gain recognized under Thatcher would increase its basis.

107. 331 U.S. 1 (1947). One of the reasons for the Crane Court's conclusion that liabilities incurred in the purchase of the asset are included in determining the basis was to avoid a fluctuating depreciable basis dependent upon actual payment of the mortgage principal. Here the same result occurs since the depreciable base is affected by the time of payment. See Treas. Reg. § 1.362-1(a) (1976). The basis determination is further dependent upon whether an aggregate or asset per asset approach is utilized in determining the corporation's basis for the assets. See B. BITTKER \& J. EUSTICE 3-43 to 3-45. 


\section{E. The Focht Decision.}

The Tax Court, after reversals in Bongiovanni and Thatcher, and consistent with its hesitancy to apply the Raich rationale, ${ }^{108}$ overruled its Raich holding in Focht v. Commissioner. ${ }^{109}$ The court employed a definitional approach. On facts similar to those in Raich, the Tax Court held:

The assumption of a deductible obligation of a cash method taxpayer is a nonrealizable event because it is improper to treat the assumed liability as income to the transferor and deny him the tax benefit for its satisfaction. However, a cash basis taxpayer transferring a nondeductible liability realizes gain irrespective of whether he enjoyed a prior tax benefit as actual payment would generate no additional tax deduction. ${ }^{110}$

Thus, the court in Focht departed from the Bongiovanni approach in that nonliability treatment is extended only to deductible obligations. A trade payable, such as a fine incurred in the course of business, might not constitute a liability for section 357 (c) purposes under Bongiovanni, while under Focht it would be included since the obligation is nondeductible under section $162(\mathrm{f}){ }^{111}$ Furthermore, the court specifically extended this definitional approach to section 358(d), clarifying the uncertainty which had existed under Bongiovanni. ${ }^{112}$

In arriving at its conclusion, ${ }^{113}$ the court reviewed the Supreme Court decision in United States v. Hendler ${ }^{114}$ and examined the legislative history of section 357, which indicated that the Hendler decision and the desire to avoid forcing businesses to liquidate liabilities prior to incorporation were the major factors behind the legislation. Given this background, the Focht court concluded that Congress intended section

108. See note 23 supra.

109. 68 T.C. 223 (1977).

110. Id. at 237-38.

111. Section 162(f) disallows a trade or business expense deduction for fines or similar penalties paid to a government for the violation of any law.

112. See note 76 supra.

113. The court relied heavily upon the law review article by Kahn and Oesterle, cited herein. 68 T.C. at 229.

114. 303 U.S. 564 (1938). In Hendler, the Supreme Court held, under the predecessor to section 351, that the assumption of secured mortgage bonds by a transferee in an otherwise taxfree reorganization constituted money received by the transferor. The court found that this money was "boot" and was taxable income to the transferor. Under such an interpretation any corporation which had received appreciated property upon its incorporation could argue that its basis for the transferred assets should be increased. Under section 362 and its predecessor the corporate basis for the assets is that of the transferee increased by gain recognized on the transfer. The Internal Reserve Service soon discovered that application of the Hendler doctrine would result in an increased basis to the corporation without the attendant increased tax liability at the corporate shareholder level since the transfers were now protected by the statute of limitations. See B. BitTKER \& J. Eustice 3-22 to 3-24. 
357(c) to apply only to the type of liabilities involved in Hendler. ${ }^{115}$ In addition, the court reviewed Crane, ${ }^{116}$ noting that a footnote to the Crane opinion indicated a concession by the Internal Revenue Service that the "amount realized" concept excludes any interest expense assumed, since its payment is a deductible expense. The court concluded that had the Supreme Court considered such an issue in Hendler it would not have reached the same conclusion. ${ }^{117}$ The Focht court considered the transferee's assumption of a deductible expense to be the equivalent of payment by the transferor: the assumption operates "as if $\mathrm{X}$ [the transferee corporation] had paid the money to $\mathrm{P}$ [the transferor] and then $P$ had paid the creditors." 118 Throughout its opinion, the court noted that the amount of gain generated and ultimately recognized by the transferee is the same as if he had continued to hold the assets individually and disposed of them in that capacity. ${ }^{119}$

\section{F. Criticism of the Focht Decision.}

The Focht rationale is subject to a number of criticisms. Since the Focht court utilized a definitional approach, many of the criticisms applied to Bongiovanni are equally applicable to Focht: inconsistent interpretation of the plain language of the statute, the uncertainty of the effect on the term "liability" as it appears elsewhere in the Code and the absence of any true support in the legislative history (especially since it is difficult to believe that Congress was focusing on a footnote cited in Crane). ${ }^{120}$ The decision also pointedly left unresolved the issue whether the transferee is entitled to deduct the payables, thereby perpetuating the confusion in this area. ${ }^{121}$

Furthermore, as noted in Judge Hall's dissent, the Focht approach is conceptually unsound because the court assumed that payment will ultimately be made and granted the taxpayer the benefit of a deduction

115. The Focht court quoted the following language from Bongiovanni: " 'tax' liabilities, i.e., liens in excess of tax costs, particularly mortgages encumbering property transferred in a Section 351 transaction." 68 T.C. at 228 (quoting 470 F.2d at 924).

116. 68 T.C. at 233-34.

117. Id. at 234 .

118. Id. at 236. This analysis is reminiscent of that adopted by the Thatcher court. See text accompanying note 92 supra.

119. Such a focus is in error as it does not take into account the multiplier effect. See notes 79-81 supra and accompanying text.

120. See text accompanying note 116 supra. See Note, supra note 30 , at 257.

121. See notes 104-07 supra and accompanying text. In Note, supra note 30 , at 254 , it is suggested that the court would not allow such a deduction and would instead force it to be a capitalized expense. Nevertheless, if a capital expense is incurred, it theoretically creates an asset that can subsequently create a loss. 
before any money passes to the creditor, ${ }^{122}$ contrary to fundamental cash basis principles. Although under Crane assumption by the transferee was considered equivalent to payment, a significant distinction exists. In a Crane situation the transferor does not maintain an interest in the transferee, while, by definition, a section 351 transferor must be in control of his transferee. If the transferee corporation fails to pay off the liability, the section 351 transferor will be economically benefited. It is anomalous to allow him to benefit through the deductibility of his payables at the time of transfer when he may also benefit by their subsequent nonpayment. ${ }^{123}$

Like its counterparts, Bongiovanni and Thatcher, Focht represents a strained effort to achieve parity without truly facing the problems involved in reaching that goal. Only by rejecting such "cut-and-paste" attempts at judicial legislation and by adopting a fundamentally different view of the statute and of the tax effects of section 351 transactions may the courts ultimately achieve true parity.

\section{Literal Application of Section 357(c)}

Even if the Raich application of section 357(c) was not contemplated by lawmakers as they sought to enact additional safeguards to shield the recognition-free nature of section 351 transactions, Congress did not see fit to enact separate protective sections to accommodate taxpayers with differing methods of accounting. Given the many uncertainties and difficulties required by the strained interpretations in Bongiovanni, Thatcher and Focht, it is appropriate to maintain that section 357(c) should be applied literally. A literal application eliminates most, if not all, of these difficulties. Those decisions ignore the fact that accrual and cash basis taxpayers are not identically situated. Rather, a taxpayer's choice of accounting methods should carry with it significant economic consequences. ${ }^{124}$ It is thus incumbent upon taxpayers and their advisors to anticipate the limitations on their business transactions caused by their chosen accounting method and to plan accordingly. As previously described, ${ }^{125}$ the application of section $357(\mathrm{c})$

122. 68 T.C. at 245 . This same criticism also appears to be applicable to Judge Hall's analysis. Id. at $245-249$.

123. Uncertainty exists as to sale treatment to the transferor if stock received in the section 351 transfer is sold before the corporate satisfaction of the transferred payables. See Brown, Incorpo. rating Transfers and Anticipatory Assignments, 38 U. PrTr. L. Rev. 589 (1977).

124. Provided that the chosen method of accounting clearly reflects income, cash and accrual basis taxpayers are similarly situated, but only so long as they continue their business as a sole proprietorship. Once the assets of the proprietorship are transferred to a corporation, significant distinctions exist since the cash basis taxpayer is transferring appreciated property.

125. See text accompanying note 56 supra. 
to cash basis taxpayers can be avoided by restructuring the section 351 transaction. The resulting changes in the nature of the transfer are economically significant and reflect basic differences between the two accounting methods. If the courts allow cash basis taxpayers to escape the consequences of section 357(c) without restructuring the transfer, distortion inevitably results. Thus, the literal application of section 357(c) to cash basis taxpayers is preferable to the three contrary judicial interpretations currently vying for acceptance. ${ }^{126}$

However, if true parity between cash and accrual basis taxpayers is desired without the necessity of such tax planning devices, a new judicial approach must be discovered. The issue today remains the same as it was the day Raich was decided: given a single statutory framework and a congressional admonition that identical tax consequences are to flow from different types of transactions available to accomplish identical results, how can parity be achieved for cash and accrual basis transferors in section 351 transactions?

\section{Achievement of Parity}

\section{A. Basic Concepts and the Failure of Current Approaches.}

The achievement of parity between cash and accrual basis taxpayers in section 351 transactions requires the recognition of two fundamental precepts. First, disparate results under section 351 are directly related to the transferors' pretransfer method of tax accounting. This discrepancy exists both in terms of bases of the assets transferred and in terms of when, by whom and with what character transferred receivables are to be included in income. Second, the call for parity must be complete across the entire spectrum of Code sections affecting section 351 transfers. Parity cannot be accomplished by corrective measures directed at a single section, specifically section $357(\mathrm{c})$, nor by favoring one taxpayer over another. Unless all differences are reconciled for all taxpayers, nothing has been achieved.

As illustrated above, ${ }^{127}$ the statutory scheme allowing recognitionfree transfers to controlled corporations cannot be manhandled so as to ensure equitable treatment for cash basis transferors. It is imperative

126. As noted throughout this Article, section 357(c) was intended to apply mechanically and to supplant the subjective criteria of section $357(\mathrm{~b})$. As one commentator has stated, "[i]t is not inconceivable that Congress chose to sacrifice economic reality in order to provide an objective guideline." Note, supra note 30 , at 257 . Furthermore, it has been noted that a literal application of section 357(c) can be argued and defended as rectifying the abuse inherent in a cash basis taxpayer's transfer of assigned income. See Kahn \& Oesterle 465. Those authors, however, disagree with such a conclusion.

127. See text accompanying notes 57-123 supra. 
to reemphasize the similarity of transfers by cash and accrual basis taxpayers. The only difference between the two, albeit a significant one, lies in their chosen methods of tax accounting.

Tax accounting methods are artificial creatures. Theoretically, any system of tax accounting may be utilized, provided that it clearly reflects income. ${ }^{128}$ However, an accounting convention must give way if income is not attributed to the party by whom it is earned.

Cash basis taxpayers do not recognize receivables as income until payment is received. ${ }^{129}$ In other words, the cash basis method of accounting does not coordinate income with the period of economic activity in which income is produced. It is precisely because income is not accounted for until received that the receivables of cash basis transferors have a zero basis. If receivables are outstanding on the date of a section 351 transfer, however, the weight of authority would allow the receivables earned by a cash basis transferor to be assigned to a controlled corporation. ${ }^{130}$ The transferee corporation would then be taxed upon the collection of those receivables, presumably at a lower corporate rate and possibly as capital gain rather than ordinary income. ${ }^{131}$ In contrast, an accrual basis transferor is deemed to have taken receivables into income when they accrued, that is, when the right to receipt arose. ${ }^{132}$ Therefore, income was reflected in the same period as the economic activity which produced it. Consequently, an accrual basis transferor is taxed directly and has no opportunity to deflect income from his receivables by shifting it to a related entity.

Those who would deny the applicability of assignment of income (and its complementary assignment of deduction) principles to correct this discrepancy fail to recognize that parity must exist for accrual basis taxpayers. Certainly, those who object to disparate treatment of cash basis taxpayers under section 357(c) cannot claim that the same cash basis taxpayer should enjoy a more advantageous tax position than that of accrual basis taxpayers. If assignment of income principles are applied, ${ }^{133}$ parity will exist for both accrual and cash basis transferors

128. I.R.C. $\$ 446$.

129. See note 3 supra.

130. See Hempt Bros. v. United States, 490 F.2d 1172 (3d Cir.), cert. denied., 419 U.S. 826 (1974); H.B. Zachary Co., 49 T.C. 73 (1967); Arthur L. Kniffen, 39 T.C. 553 (1962); Thomas W. Briggs, 15 T.C.M. (CCH) 440 (1956); Rev. Rul. 69-102, 1969-1 C.B. 32; Kahn \& Oesterle 476.

131. The character of an asset-capital or ordinary-is determined by applying section 1221 to the taxpayer. While section 1221(4) provides that accounts receivable acquired in the ordinary course of a trade or business are a non-capital asset, the issue remains in a transferee situation whether the subsection is limited to the taxpayer's own business.

132. See note 3 supra.

133. Some support exists for the application of this doctrine. See B. BITTKER \& J. EUSTICE 359; Biblin, Assignments of Income in Connection With Incorporating and Liquidating Corporations, 
under section 351 and the problems and uncertainties created by the Raich, Bongiovanni, Thatcher and Focht decisions will be eliminated.

\section{B. A Proposed Solution-The Assignment of Income Doctrine.}

The doctrine of assignment of income reaches those situations where income has been earned by one taxpayer and has been assigned to another taxpayer before collection has been made. ${ }^{134}$ Although section 351 provides generally for nonrecognition of realized gain if its requirements are met, nothing in that section precludes application of the assignment of income doctrine. ${ }^{135}$ The gain which Congress intended to escape recognition in a section 351 transaction is gain flowing from the exchange itself, not income earned from operations concluded before the transfer takes place. ${ }^{136}$ The section does not state that potential income items are to be taxed to the transferee corporation or that the payables are to be deducted by the transferee. ${ }^{137}$ Although section 362 provides that the transferee corporation will acquire the transferor's basis in the property transferred, and thus will realize the same gross amount of income upon collection, the income collected fre-

1969 S. Cal. TAX INST. 383; Brown, supra note 123. The judicial treatment of the doctrine is discussed in detail in text accompanying notes 152-92 infra. The application of the doctrine is not subject to the objection that it will conflict with the policy of section 351 transfers. As stated so well by Brown, supra note 123, at $626 \mathrm{n} .156$, "no conflict occurs from an application of assignment principles to organizational transfers; transferors are taxed no earlier and on no greater amount than would have eventuated absent incorporation of their enterprise."

Such an approach should be contrasted with that used in the case of Commissioner v. P.G. Lake, Inc., 356 U.S. 260 (1958), where a sale occurred for which the consideration was the transfer of a right to receive future income. Because the transaction was characterized as a sale, immediate recognition of income was required; the only issue was the character of the gain. In the assignment of income situation, the transaction may not be treated as a sale and thus immediate income recognition would be inappropriate.

134. The simplest example is a cash basis taxpayer who has rendered his professional services, billed his client and is merely awaiting payment. Under his accounting method he has no income until receipt. If the taxpayer were to transfer the receivable, pursuant to section 1015 , as a gift to his child, substantial tax savings would arise since the child is in a lower tax bracket. However, application of the doctrine would require that the payment be viewed as one to the taxpayer, resulting in ordinary income to him, with a subsequent transfer of the proceeds as a gift to the child. For monumental works on the doctrine, see Eustice, Contract Rights, Capital Gain, and Assignment of Income-the Ferrer Case, 20 TAx L. Rev. 1 (1964); Lyon \& Eustice, Assignment of Income: Fruit and Tree as Irrigated by the P.G. Lake Case, 17 TAx L. REv. 293 (1962).

135. It should be remembered that the doctrine is judicial in origin and overrides statutory provisions. Thus, in the example at note 134 supra, the taxpayers would argue that sections 102 and 1015 protect the transferor. Nonetheless, the judicial doctrine controls.

136. As stated by Brown, supra note 123, at 603 , "[t]he transfer of pure income items is not reached by the statute. Moreover, section 351 essentially deals with timing of the tax impact-it grants postponement-whereas the assignment cases address the issue of taxpayer identity, and have no bearing on timing." (Emphasis in original; footnote omitted.)

137. Judicial interpretations and a ruling by the IRS allow such results. Rev. Rule. 69-102, 1969-1 C.B. 102. 
quently will be taxed at a preferential rate. It should be noted that in Helvering $v$. Horst ${ }^{138}$ a classic application of assignment of income principles, the donee/transferee also took a carryover basis. However, the court reasoned that the shift in taxpayers triggered the doctrine's application notwithstanding that the income would have been taxable to the donee. In theory, therefore, nonrecognition treatment under section 351 and assignment of income principles are not inconsistent. ${ }^{139}$

If assignment of income principles are applied with respect to the receivables of a cash basis transferor, those receivables will be taxed as income to the transferor when they are collected by the transferee corporation. Additionally, the payables will generate deductions to the transferor when the corporation pays them. ${ }^{140}$ In essence, the corporation is the transferor's agent with respect to those items. Tax dollars will not escape, since income will no longer be taxed at a lower corporate rate. ${ }^{141}$ Thus, parity will be achieved vis-a-vis accrual basis taxpayers who directly realize taxable income on pretransfer accounts receivable. More importantly, the application of assignment of income principles will insulate cash basis transferors from gain recognition under section 357 (c) with respect to transferred payables. ${ }^{142}$

Generally, in assignment of income situations that involve a cash basis taxpayer, the transferor will not realize the income until collection is made by the assignee. ${ }^{143}$ This treatment is clearly consistent with general cash method accounting principles. The cash basis transferor remains the "owner" of the receivables, which represent a fully earned right to income in his hands; under the doctrine, he is deemed unable to transfer this right to income until the collection date. Therefore, until receivables are actually collected and the proceeds retained by the transferee, the transferor is not treated as having exchanged that property. Thus, only assets other than receivables would come within the section 351 incorporation transfer. ${ }^{144}$

138. 311 U.S. 112 (1940). Horst involved a factual situation similar to that described in note 134 supra.

139. See Brown, supra note 123, at 603-13.

140. The rationale for applying a concept similar to the assignment of income doctrine to deductible items of expense transferred in a section 351 exchange is discussed in the text accompanying notes $145-47$ infra.

141. See text accompanying note 131 supra.

142. See text accompanying notes $148-51$ infra.

143. See Helvering v. Eubank, 311 U.S. 122 (1940); Biblin, supra note 133, at 385. This approach, which is consistent and adopts an agency approach, should be contrasted with some proposals requiring an accrual of receivables and payables on the date of incorporation. See Comment, NEB. L. REv., supra note 2, at 552.

144. Section 351 treatment would apply to the transfer of the other assets; yet, the assigned receivables would be viewed as a separate transaction-one of agency. In essence, those assets 
Conversely, it is generally held that deductions may be taken only by the party incurring the expense. ${ }^{145}$ Cash method accounting principles provide that an expense is not deductible until it has been paid. Therefore, it would follow that the deductions flowing from the accounts payable incurred by a cash method transferor would not become available upon the transfer to and assumption by a transferee corporation, but only upon satisfaction of those payables by the transferee. ${ }^{146}$ Because the deductible expense was incurred by one taxpayer (the transferor) and paid by another (the transferee), it is unclear who should receive the benefit of the deduction. The agency concept underlying the assignment of income doctrine is consistent with the holding that payment is made by the transferee as agent of the transferor and, thus, that the transferor should be able to claim a deduction from his income when his business expenses are actually paid. ${ }^{147}$

Under this analysis, section 357(c) gain due to payables and receivables is eliminated, since the operation of the assignment of income doctrine, together with the cash method of accounting, precludes the transfer of zero basis receivables. When the corporation subsequently collects the receivables, the cash basis transferor realizes income. Similarly, he is credited with a deduction when the corporation satisfies trade payables. The excess of receivables over payables is considered to be transferred subsequent to the original section 351 exchange in a separate and independent transaction. This constructive transfer may be treated as a contribution to capital or as a subsequent section 351 transfer, provided the transferor is in control of the corporation on the

would continue to remain the property of the transferor, although his agent (the corporation) is deemed to collect them.

145. See Brown, supra note 123, for a discussion of alternative considerations respecting this deduction concept. Throughout tax law, deductions have been denied for taxpayers who pay another taxpayer's expense, since section 162, which allows deductions for trade or business expenses, implicitly requires that the expenses arise in the taxpayer's business. See I.R.C. \$ 162(a); Treas. Reg. \& 1.162(1). See also Del Cotto 10 n.41.

146. The statutory concept of liability acquisition by a corporation and its proper treatment is a separate notion from the deductibility of the liabilities acquired. In the same fashion in which the transfer of accounts receivable is distinguished from the transfer of qualifying section 351 property, a similar distinction could be drawn between accounts payable and Section 357 liabilities. This distinction is not premised on the holdings of Bongiovanni and Thatcher, since those holdings do not address both issues, but instead upon the assignment of income doctrine. See also Brown, supra note 123, at 600-02.

147. One of the major uncertainties throughout sections 351 and 357(c) is whether the transferee corporation is entitled to deduct the payables. This uncertainty is eliminated by applying the assignment of income doctrine, since the premise of the doctrine is that both income and deductions, i.e., all current everyday operating events, are attributable to the party incurring them. Furthermore, equity considerations require that if a taxpayer is taxed on assigned income items, he should be able to offset such income by the payment of assigned payables. See generally Lyon \& Eustice, supra note 134, at 411-15. 
date of receipt. ${ }^{148}$

Applying this analysis to the hypothetical situation discussed above, ${ }^{149}$ complete parity would be achieved between the hypothetical cash and accrual basis taxpayers. Each would recognize ordinary income from accrual or collection of receivables and would be entitled to deductions from accrual or payment of payables. Neither would recognize gain on the completed section 351 transaction and each would have a basis of $\$ 15,000$ in his shares of the transferee corporation. In either case, the corporation would have a basis of $\$ 15,000$ in the remaining tangible assets transferred.

In sum, if assignment of income principles are applied, complete parity is achieved. The cash basis taxpayer escapes gain recognition generated by section 357(c), yet is taxed in full upon pretransfer receivables as is an accrual basis transferor. Furthermore, this theory is faithful to the precepts underlying a successful analysis of parity under section 351 as outlined above. It recognizes that disparities do flow directly from chosen methods of accounting and provides complete equivalence across the entire section 351 transaction for both accrual and cash basis transferors. At the same time, this analysis honors both the validity of the underlying statutory scheme and the validity of differing methods of tax accounting. In contrast to some suggestions that the transferor be forced onto an accrual basis method of accounting, ${ }^{150}$ which would require immediate taxation, the assignment of income analysis continues to honor the transferor's cash basis method of accounting, with recognition postponed until actual collection or payment. This approach utilizes a doctrine which permeates all of taxation in order to ensure similar tax consequences for similarly situated taxpayers-an enunciated goal of section $351 .{ }^{151}$

148. In actuality, the corporation is transferring stock for the value of the excess of receivables over payables. Valuation difficulties obviously attach. The transaction may technically be viewed as receipt of stock which is unpaid, with payment occurring upon collection and payment of the assigned assets and liabilities. Under any interpretation the results should be identical.

In those rare situations in which the value of accounts payable exceed accounts receivable, the income deduction effects will continue, but at the point at which the final amount of receivables collected are exceeded by the amounts paid, the issue of the "source" of the funds through which the excess payables are satisfied and the attendant tax consequences of such satisfaction must be considered. While a number of alternatives exist, the most rational explanation, especially since the source of the additional funds is probably subsequent corporate earnings, is to conceptualize the excess payables (deductible by the transferor) as paid with funds distributed by the corporation generating a dividend to the extent of earnings and profits. See I.R.C. $\$ \$ 301$, 312, 316. See generally B. BITTKER \& J. EUSTICE ch. 7.

149. Sce text accompanying notes 31-36 supra.

150. Comment, supra note 143.

151. See note 23 supra. 


\section{Judicial Treatment of Section 351 and the Assignment of Income Doctrine.}

Unfortunately, the courts have not embraced the assignment of income doctrine as a solution to the current disparity under section 351 . The cases have not applied assignment of income principles to attribute the ownership of cash basis receivables to cash basis transferors with the attendant tax consequences. These opinions are subject to criticism.

The prevailing view appears to be that the assignment of income doctrine may not be applied to section 351 transfers to controlled corporations. ${ }^{152}$ However, the cases most often cited in support of this position fail to discuss assignment of income principles altogether. In Thomas $W$. Briggs ${ }^{153}$ all the assets of a cash basis sole proprietorship were transferred to a new corporation in a section 351 transaction. Included in the assets transferred were trade receivables which had not been collected by the transferor. ${ }^{154}$ The Commissioner argued that these receivables should be taxed to the transferor, not to the transferee corporation. In support of his contention, the Commissioner relied upon his power to reallocate items of income and to force a change of the taxpayer's accounting method in order to clearly reflect income. ${ }^{155}$ The Tax Court rejected the Commissioner's theories out-of-hand. It held that the receivables were properly taxable to the transferee corporation, not to the transferor. ${ }^{156}$ However, nowhere in the opinion did the Tax Court recognize or discuss assignment of income principles.

Similarly, in Arthur L. Kniffen ${ }^{157}$ a sole proprietorship using the cash basis method of accounting transferred all the assets of its real estate business to a newly formed corporation in exchange for all of the corporation's stock. Two notes were included in the assets transferred. One was a promissory note with accrued interest. The other represented a commission for services rendered in connection with a sale of real estate. ${ }^{158}$ The Commissioner argued that the accrued interest on

152. See Kahn \& Oesterle 476, in which they state:

It appears inappropriate to apply [the assignment of income doctrine] to the transfer of income-producing assets (including accounts receivable) of a going business, at least where the assets are such as are typically held by such businesses and where, therefore, no tax avoidance purpose appears to have motivated the transfer. Application of the assignment of income doctrine to such assets in section 351 transfers would undermine Congress' policy in adopting that section, namely, the removal of tax impediments to incorporation and some types of corporate reorganizations.

153. 15 T.C.M. (CCH) 440 (1956).

154. Id. at 447.

155. Id. at 451.

156. Id.

157. 39 T.C. 553 (1962).

158. Id. at 565 . 
the first note and the principal of the second were not properly taxable to the transferee corporation, but rather to the transferor. ${ }^{159}$ As to both notes, however, the Tax Court held that the income in question was taxable to the transferee corporation. The court based its holding upon the fact that the overall transaction qualified for nonrecognition treatment under section $351 .{ }^{160}$ As in Briggs, the court did not discuss the assignment of income doctrine.

These cases apparently stand for the proposition that once section 351 is found to apply, and the transaction thus qualifies for nonrecognition treatment, application of the assignment of income is inappropriate. However, subsequent statements by the courts indicate that this proposition has been considerably weakened, if not overruled.

In Divine $v$. United States ${ }^{161}$ a real estate partnership transferred notes, derived from the sale of real estate, to a controlled corporation in exchange for stock. ${ }^{162}$ Once again the Commissioner contended that the income generated by pretransfer sales and represented by the notes was properly taxable to the transferor partnership. ${ }^{163}$ The court considered all of the leading assignment of income cases and concluded in dictum that the same principles would seem to apply in the section 351 context. Indeed, the court stated that anticipatory assignments of income presented an issue entirely different from the question of recognition of gain or loss in a section 351 transaction. ${ }^{164}$ However, citing Briggs, the court retreated from its position and concluded that since assignment of income principles would "revolutionize" the area it should adhere to precedent. ${ }^{165}$

The Tax Court moved more definitely toward accepting the applicability of assignment of income principles to section 351 transactions three years later in Weinberg $v$. Commissioner. ${ }^{166}$ The petitioner in Weinberg was engaged in a farming business in California's Imperial Valley. Upon the advice of his accountants, and in view of his poor health, he decided to turn over part of the farming operation to a

159. Id. at $564-65$.

160. Id. at 564-66.

161. 62-2 U.S. Tax Cas. 85,589 (W.D. Tenn. 1962).

162. Id. at 85,590 .

163. Id.

164. Id. at 85,593 .

165. Id. at 85,594 . It is noteworthy that other courts in various situations have applied the doctrine. See e.g., Palmer v. Commissioner, 267 F.2d 434 (9th Cir.), cert. denied, 361 U.S. 821 (1959); Brown v. Commissioner, 115 F.2d 337 (2d Cir. 1940); cases cited at Kahn \& Oesterle 476 n.74. In view of these cases, application of the doctrine would not have been as revolutionary as the Divine court postulated.

166. 44 T.C. 233 (1965), modified, 386 F.2d 836 (9th Cir. 1967), cert. denied, 392 U.S. 929 (1968). 
number of small corporations. He instructed his attorney to form the corporations and planned to transfer certain growing crops and $\$ 1,000$ in cash to each in exchange for stock. However, the court determined that the crops had been sold before the transfer was complete and, thus, only the rights to the proceeds were transferred to the corporation. ${ }^{167}$ The Tax Court determined that the crops were the property of the transferor when they were sold and that the proceeds from this sale were income to the transferor. As an alternative ground, the court confronted the transferor's argument that application of income assignment principles was inconsistent with the nonrecognition provision of section 351. ${ }^{168}$ Citing examples of in kind distribution to shareholders found to be assignments of income, ${ }^{169}$ the court reached the contrary conclusion:

The impact of the [United States v.] Lynch and A.B.C.D. Lands, Inc. cases and the authorities there relied upon is not lessened by the fact that the purported assignments of the crops here were made by the stockholder to his corporations rather than by a corporation to its shareholders. Nor does the applicability of the rule require a determination as to whether there were effective assignments of growing or harvested crops. If the assignments were of income already earned whether or not their purpose was tax avoidance, they do not shift the burden of tax on such income. ${ }^{170}$

The Tax Court did not cite its prior decisions of Kniffen, Briggs or Divine, which seemingly would have required a holding that the assignment of income doctrine was inapplicable.

It is difficult to reconcile Weinberg with Kniffen, Briggs or Divine. As one author points out, Weinberg could be distinguished on the grounds that only the rights to proceeds from a single asset were transferred, whereas in the other three cases the entire underlying business was exchanged. ${ }^{171}$ However, assignment of income principles should reach assigned income regardless of whether the assignment accompanies the transfer of other property. The assignment of income doctrine applies so long as earned income has been shifted to a taxpayer who

167. 44 T.C. at 241 . To this extent, the court actually employed a constructive receipt analysis.

168. Id. at 242 .

169. Id. The cases cited by the court involved transactions in which the transferor had performed the services required for receipt of the income and subsequently distributed the receivable to its shareholders as a dividend on liquidating distribution. Income was not deflected since the transfers constituted anticipatory assignments of income.

170. Id. at 245 (emphasis added). The cases cited by the court are United States v. Lynch, 192 F.2d 718 (9th Cir. 1951), cert. denied, 343 U.S. 934 (1952) and A.B.C.D. Lands, Inc., 41 T.C. 840 (1964).

171. See Biblin, supra note 133, at 393. 
did not earn it. ${ }^{172}$

Further support for the proposition that Weinberg overruled the earlier line of cases is found in dicta in the Tax Court's decision two years later in H.B. Zachary, ${ }^{173}$ which clearly implied that the application of assignment of income principles was not inconsistent with nonrecognition treatment under section 351. In Zachary, the court held that a carved out oil payment was to be considered property for purposes of section $351 .{ }^{174}$ Although such payments had previously been subject to assignment of income principles, the court specifically stated that the issue was not before it. Consequently, it appears that nonrecognition and assignment of income are to be treated as separate and distinct issues; a resolution of one-the applicability of nonrecognition provisions-is not determinative of the applicability of the assignment of income doctrine.

Unfortunately, these promising signs that the Tax Court has reconsidered its earlier position that the assignment of income doctrine is inapplicable to section 351 transactions were apparently ignored by the Third Circuit in the most recent case presenting this issue. In Hempt Bros. v. United States, ${ }^{175}$ the court squarely held that receivables transferred to a controlled corporation in a section 351 incorporation exchange were taxable to the transferee corporation and not to the transferor. ${ }^{176}$ Although the court disavowed the applicability of assignment of income principles, ${ }^{177}$ its holding was limited to the facts before it; the court disclaimed any intent to promulgate a universal rule and expressly reserved the issue of the applicability of assignment of income principles to tax avoidance situations. ${ }^{178}$

In Hempt Bros. a family-owned cash basis partnership transferred its business and most of its assets pursuant to section 351 to a newly formed corporation in exchange for stock. Included among the assets transferred were accounts receivable in the amount of $\$ 662,824.40$ attributable to sales completed before the date of transfer. After a finding that the new corporation should use the accrual method of tax accounting, the Commissioner assessed deficiencies for the corporation's first two fiscal years based upon its collection of the transferred

172. See Lucas v. Earl, 281 U.S. 111 (1930).

173. 49 T.C. 73 (1967).

174. Id. at 80 . The "carved out" oil payment was a right to receive a specified amount payable out of funds derived from a one-eighth interest in oil and gas properties.

175. 490 F.2d 1172 (3d Cir.), cert. denied, 419 U.S. 826 (1974).

176. Id. at 1178 .

177. Id.

178. Id. 
receivables. ${ }^{179}$ The corporation paid the deficiency plus assessed interest and filed a claim for refund asserting that, under the assignment of income principles of Lucas $v$. Earl, ${ }^{180}$ the predecessor partnership was the proper taxpayer.

The court acknowledged that the case presented an illustration of conflict between statutory and judicial tax rules. While not finding fault with the general precepts of the assignment of income doctrine, the court concluded that to apply the doctrine to these facts would hamper the incorporation of ongoing businesses. ${ }^{181}$ However, the legislative history cited in support of this conclusion ${ }^{182}$ gives no indication that the application of long-standing and pervasive doctrines such as assignment of income would be economically unsound. Indeed, the relevant House and Senate reports appear to modify only the tax treatment of income realized through the section 351 exchange itself, not of income arising from pretransfer activities.

Citing section 358 , the court reasoned further that the transferor retained the potential of realizing income through the subsequent sale or other disposition of stock received in the section 351 transaction. ${ }^{183}$ However, the court failed to appreciate that this gain will typically be taxed as long term capital gain and can be spread out over a number of years by periodic dispositions of stock, unlike the ordinary income generated by the application of the assignment of income doctrine at the time the receivables are collected. ${ }^{184}$ Such potential gain is no substitute for proper income recognition via the assignment of income rules.

The district court opinion in Hempt Bros. ${ }^{185}$ puts into sharp relief

179. Id. at 1175. The deficiencies were assessed six and one-half years following the close of the corporation's first fiscal year.

180. 281 U.S. 111 (1930). See text accompanying note 172 supra.

181. 490 F.2d at 1177 . The court expressly disclaimed any intention of promulgating a hard and fast rule in this area, preferring to reach decisions on the basis of a case by case factual analysis. 490 F.2d at 1178 . Moreover, it limited application of the doctrine to tax avoidance situations. Id. However, it should be noted that authoritative cases in the assignment of income area have not required a tax avoidance purpose to justify the doctrine's application. See, e.g., Harrison v. Schaffner, 312 U.S. 579 (1941). Thus, the court was in error. See Brown, supra note 123, at 627. See also Weinberg v. Commissioner, 44 T.C. 233, 245 (1965), modified, 386 F.2d 836 (9th Cir. 1967), cert. denied, 392 U.S. 929 (1968) quoted at text accompanying note 170 supra.

182. See authorities cited at 490 F.2d at 1177 n.7.

183. 490 F.2d at 1178. This potential lies in the carryover basis for the transferor's stock, which preserves the gain potential of appreciated assets to be recognized upon subsequent disposition of the stock.

184. See note 77 supra. Section 453 permits an election of installment reporting if certain statutory criteria are satisfied. Such an election would further defer the.tax consequences. Although the court indicated that the fact that the statute of limitations had run as to the partnership transferor did not have any effect upon its decision, one must suspect that, in the court's case by case approach, this factor was of significant importance. 490 F.2d at 1176 n.4.

185. Hempt Bros. v. United States, 354 F. Supp. 1172 (M.D. Pa. 1973). 
the importance of the assignment of income doctrine to the achievement of full parity. Before the lower court, the petitioner had cited $E$. Morris Cox ${ }^{186}$ for the proposition that amounts collected on receivables transferred to a corporation are properly attributable to the transferor. ${ }^{187}$ The district court distinguished Cox on the grounds that in that case the transferor, employing an accrual method of accounting, had realized income when billings were made and, thus, that the result there was consistent with the carryover basis provisions of section 362. ${ }^{188}$ What Cox illustrates, however, is that a section 351 transfer short-circuits the clear reflection of income normally achieved under a cash basis accounting system; accrual basis taxpayers are placed at a relative disadvantage because they are unable to transfer realized but uncollected and unrecognized receivables to a controlled corporation.

It would seem, given the split between the Third and Ninth Circuits, that the case law on this question is inconclusive and certainly at odds with sound policy. In support of the argument that the assignment of income doctrine should apply to section 351 transactions, it should be noted that the doctrine has been applied in the context of other nonrecognition sections of the Code. ${ }^{189}$ For example, these principles have been found to apply to corporate liquidations and distributions. ${ }^{190}$ If earned income items are distributed to shareholders in liquidation, the corporation must recognize the income upon their collection by the shareholders. ${ }^{191}$ This application overrides the general nonrecognition treatment afforded to liquidating corporations by section 336. ${ }^{192}$ Thus, one cannot argue that a statutory nonrecognition provision prevents the application of the assignment of income doctrine.

186. 43 T.C. 448 (1965).

187. 354 F. Supp. at 1180.

188. Id. at 1180-81.

189. Distributions within the nonrecognition provisions of sections 311,336 and 337 have been subjected to the assignment of income doctrine. See B. BITTKER \& J. EUSTICE 7-41 to 7-47 (discussing inter alia Commissioner v. First State Bank of Stratford, 168 F.2d 1004 (5th Cir.), cert. denied, 355 U.S. 867 (1948)), 11-48 to 11-49 (citing J. Ungar, Inc. v. Commissioner, 244 F.2d 90 (2d Cir. 1957)), and 11-69 to 11-71.

190. See B. BitTKer \& J. Eustice 11-69 to 11-71.

191. It should be noted that the time for imputation of income may be affected by whether collection of the income items occurs before or after completion of the liquidation. See Sol C. Siegel Prod., Inc., 46 T.C. 15 (1966).

192. It may be that the courts will be less willing to apply [the assignment of income doctrine] if the corporation completely liquidates than if the shareholders receive the property in an ordinary distribution or partial liquidation, for the reason that a complete liquidation usually has more drastic nontax consequences and is less likely to be employed principally for tax avoidance.

B. BrTTKER \& J. EUSTICE 11-49. However, this rationale certainly is not applicable to a section 351 transfer. 
Even if the Hempt Bros. rationale prevails and the assignment of income doctrine is held inapplicable to section 351 transfers in general, it may properly be applied to potential section 357(c) situations. Section 357(c) was enacted to prevent tax avoidance without inquiry into subjective factors. ${ }^{193}$ It is therefore arguable that section 357 (c) situations carry with them the tax avoidance possiblities with which the Hempt Bros. court was concerned and as to which it reserved judgment. While the Hempt Bros. court probably considered only intentional efforts to avoid tax, section 357(c) situations may raise similar difficulties requiring application of the assignment of income doctrine for their successful resolution.

\section{Conclusion}

Much has been written concerning the burdensome application of section 357(c) to cash basis transferors in section 351 exchanges. Much has been said about the "artificial gain" generated by an unfortunate choice of accounting method. Yet very little has been offered to explain why accrual basis transferors should suffer an equivalently inherent disadvantage if the application of section 357(c) to cash basis transferors is limited.

Parity among similarly situated taxpayers is a legitimate objective of tax policy. Efforts to harmonize treatment of cash and accrual basis transferors in section 351 exchanges therefore cannot be one-sided. Inbalance will persist until the disadvantages to the accrual basis transferor resulting from its method of accounting have been eliminated.

Section 351 is designed to facilitate change in forms of business operation. The business changes only in form; underlying facts remain the same. Therefore, a cash basis transferor should not be able to assign previously earned income to be taxed at the lower corporate rate when that transferor has undergone a change of form only. Assignment of income and deduction principles and complementary statutory provisions must apply to the underlying facts. Those who criticize the "arbitrary" application of section 357(c) to cash basis transferors must applaud efforts to achieve true parity over the entire transaction.

Taxation must go to the substance of a transaction. Consequently, where similarly situated taxpayers are engaged in identical transactions, policy is frustrated when tax applications produce radically different results. Taxation should reflect reality. Because the assignment of income and deduction doctrines go to the substance of a

193. See note 30 supra and accompanying text. 
transaction and place tax burdens and benefits upon the party who has earned them, they are uniquely suited to advance tax policy and to achieve the fairest results across the broadest range of situations.

If, however, the courts refuse to apply assignment of income principles to a cash basis transferor so as to create true parity between taxpayers in section 351 transactions, then any attempt to limit the application of section 357(c) is in error. Section 357(c) continues to be an essential link in safeguarding nonrecognition transactions from abuse. If courts are unwilling to recognize that the application of assignment of income principles would preserve statutory provisions and accounting conventions intact while achieving full parity, cash basis transferors and the courts must be willing to accept the consequences of section 357(c). 